\title{
From America to Africa: A Parallel in the Colonial and Federal Experiences
}

\author{
Didier Kombieni \\ English Department, University of Parakou, Parakou, Benin \\ Email: kombidid@yahoo.fr \\ Received 1 September 2015; accepted 9 October 2015; published 14 October 2015 \\ Copyright (C) 2015 by author and Scientific Research Publishing Inc. \\ This work is licensed under the Creative Commons Attribution International License (CC BY). \\ http://creativecommons.org/licenses/by/4.0/ \\ C) (7) Open Access
}

\section{Abstract}

The present article aims at exhibiting similarities within the colonial experiences and the federal experiences of America and Africa, despite the disparities with the two processes, then pointing out the stepping of the African countries despite their moving from the Organization of the African Unity (OAU) to the African Union (AU). In effect, this change could just be seen as an awkward imitation of the American successful federal process, from the Articles of Confederation to the United States of America, since America had been senior in that process. From then, further research might decide to project what Africans could use as a frame of reference in their American equivalent concerning the search for an integrated society, and an accepted democracy among the separate and equal nations.

\section{Résumé}

Le présent article vise à révéler les similitudes entre les expériences coloniales et fédératives des Etats Unis d'Amérique et l'Afrique, en dépit des disparités dans ces deux processus. Il s'agira également d'insister sur le piétinement ou le manque de progrès des Etats africains dans leur passage de l'OUA à l'Union africaine, toute chose qui semble pourtant se calquer sur la réussite fédérative de l'Amérique qui est passée des Articles de confédération aux Etats Unis d'Amérique. Ainsi le chemin est balisé pour de futures recherches sur ce en quoi l'Afrique pourrait en l'état actuel emprunté à l'expérience fédérative des Etats Unis dans sa quête d'une Afrique intégrée et d'une réelle démocratie.

\section{Keywords}

Africa, USA, Similarities, Colonial Experience, Federal Experience, OAU, AU, Articles of Confederation 


\title{
Mots Clés
}

\author{
Afrique, USA, Similitudes, Expérience Coloniale, Expérience Fédérative, OUA, UA, Articles de \\ Confédération
}

\section{Introduction}

Today, Africa is described from inside and outside as a continent in a very bad position economically, socially and politically. Some examples to justify this assertion are the many challenges that the continent is facing, and which can be summed up in misery, diseases, and lack of democracy.

It is common to hear people, Africans in particular, considering the African predicament as a fatality, therefore irremediable. Others attribute the entire situation to the colonial destructive exploitation. However, the best approach to the African situation, as for me, is the economic dependency of most African states on western countries, which consequently implies their political dependency. In this respect, everyone should agree that those African states are really not independent as they pretend to be, with gorgeous annual celebration of pretended independence days. Truly, African states are still under domination, both economically and politically, and even if some of them seem to be aware of their current condition on the international level, one hardly notices a real will for finding solutions to remedy the situation. It is evident that many institutions have been founded on regional and continental level such as the Organization of the African Unity (now turned into the African Union), with the aim to eradicate the persistent problems faced by African states. But, to what extent have these contributed to Africans' welfare so far? It is just a pity that, in the face of the many challenges confronting their continent, Africans have persisted with those weak organizations, which have failed to reach the minimum of their objectives as stated, for instance, in the charter of the African Union: continental integration of the African peoples, and development. Indeed, neither OAU nor its successor AU have had any such power over individual states, and being rendered so powerless, those organizations couldn't settle the various civil wars, crisis and attacks throughout the continent, they couldn't prevent or settle the putsches and dictatorship on the African continent either. Nor could they act in a trustfully representative way when dealing with international institutions and western governments.

Yet, a paradigm could be found between part of the story of the African continent as a whole and that of the United States of America. It is true that Africa and America don't necessarily have much in the way of common history, social constructs, or even comparable environments; but an informal comparison is possible as far as their colonial experiences and experiences within a federal framework are concerned.

The analysis here will consider two main points in the American history: from colonies to independence, then from the confederation to the federation, both events essential to the current political and social climate, and worldwide position of the United States, so as to deduce how the USA could be, not a perfect model, but at least an advisable reference for Africa.

\section{The Colonial Systems of Exploitation of Africa and America}

Although there is no real similarity between the system of colonization of America and that of Africa, some common elements appear and can favor a more or less informal comparison.

\subsection{The Political and Administrative Systems}

Of the fifty states that form the USA today, only thirteen had lived under the colonial ruling of Great Britain. They are New Hampshire, New York, New Jersey, Delaware, Connecticut, Maryland, Virginia, Pennsylvania, North Carolina, South Carolina, Massachusetts, Rhode Island and Georgia. As such, to talk about the USA before independence is to refer to those thirteen colonies. As for Africa, there has been no expansion and even if some new states have come, they are simply offshoots of other states, as it has been the case with Erytrea and South Sudan. As a whole, the system of colonization in both America and in Africa allowed colonial powers to take advantage of the colonies. In America, for instance, the thirteen colonies were under the ruling of the Crown, with the British parliament deciding for the colonies' life. Taxes were imposed; internal and external 
trades were controlled by the parliament in Britain, where Americans were not represented. That is what later made the colonies qualify such a parliament as an imperial parliament. But Americans were from British and European origin; as such, they were not so much strangers nor different from the British in their mind, and the Crown just considered them as offspring of Europe, if not of Britain. This justifies the fact that internally, Americans were in full emancipation; they could study at a very high level; they could practice the profession of their choice. All that the British authorities expected from the thirteen American colonies was to remain dependent on Britain, then to be exploited. The positive consequence is that there were Generals in the American Local Army; there were lawyers and many other learnt people from different fields of activity, who later on led the colonies to independence and who favored the success of the post-independence life of the states, and mainly the success of their federation, of their republic. Such has not been exactly the case with Africa.

Indeed, the system of colonization of Africa, not only favored exploitation of the colonies, but it also put the Africans in general at a scale which made of them less than human beings. Colonization did not accept that all Africans be formally educated; only a few Africans could go to school so as to come at the service of the colonizer. The political and administrative systems prevailing in Africa before colonization were destroyed. In short, it can be said that the difference between the system of colonization of America and that of Africa lies in the fact that, while all the thirteen American colonies were set under a uniform exploitation system from the same European country, African colonies were submitted to diverse exploitation policies; yet, at least, both America and Africa were European colonies, and this is what I aim at pointing out as similarity.

\subsection{The Socio-Economic Systems of Exploitation in American and African Colonies}

After the French-British clash in Canada (1756-1763), Great Britain, although victorious, was faced with problems bond to loss of control over her American colonies, due to great financial difficulties resulting from the war expenses. In order then to refill the country's coffers, the British parliament decided to impose new taxes and harden the existing ones on the American colonies. "Unless the taxpayer in England was to supply all money for the colonies' defense, revenues would have to be extracted from the colonies through a stronger central administration, which would come at the expense of colonial self-governments" [1]. Those measures caused Americans, who until now asked nothing but remain subjected to the Crown, to protest, rebel, and thus, the idea of departing from the mother country was born, which led to the war for independence.

On the other side, in Africa, the system of colonization was a double edge sword, and its consequences on the colonies were two fold. On the one hand, it allowed colonial extraction of raw materials and despise of the African people, as well as the decisive participation of the continent in the two world wars. On the other hand, it led to the consciousness of the colonies, and forced them to look for their own destiny, claiming their own independence. Here again, the similarity between the two courses of history is that the European exploitation practices have finally urged both Africa and America to express their being fed up with colonization, and to claim independence, which they both obtained, although the means are different. What then has been the sense given to their independence by Africans and Americans?

\subsection{Independence as a Revolution for Both America and Africa}

The USA as a political entity was undoubtedly created by a revolution, which found its expression in the Declaration of Independence of 1776. The experience of revolution therefore is one which Americans could share with other nations, especially those who like Africa, had experienced colonization. In the present article, it is to see the American Revolution in a comparative light, asserting both resemblance and differences between it and Africa. But what is a revolution first? It's a quantitative and qualitative change within a society, and such has been exactly what Africans, the people in particular, have been claiming for so long, which means that they haven't got it yet. The American Revolution was not truly aimed at any internal change at all. Rather, it was a reaction to stop external interference of England in American affairs. At such, this even took some analysts to think that there was really no revolution in America at all in the 1770s, in the modern sense of the word, but only a successful war for independence which removed British control but left the country internally much the same. Such view on the American Independence could be accepted since the rebellion against the mother country was motivated by the will to preserve old liberties against novel demands by Great Britain, something comparable to the revolt of the Belgian estates in 1789 against the attempted reforms of Emperor Joseph II. But in the case of the African colonies, if any revolution, the shift to independent entities was really different. There 
were no such national uprisings in the colonies, as it was the case with Americans. The African people at large was not truly concerned with the claim for independence because many did not know what the few elites were claiming due to illiteracy and ignorance. Even if people sided with those soldiers coming back from the world wars and the few leaders who had the opportunity to be educated in Europe in the claim of independence, there was no such violence as in the case of the Americans. As a matter of fact, the African independence came as a gift rather than a merit. In America, the long opposition to reforms from Britain and the preparation of the war for independence had allowed the colonies to get ready for the aftermath of independence, which they even declared unilaterally years before the war for independence was ended. In effect, how can it be conceived that the Peace treaty that marked the end of the war aiming at independence was signed in 1783, while independence is said to be obtained in 1776? What, if Americans did not finally win the conflict? Such reality is just to show that Americans were really prepared for their independence, contrarily to Africans. Americans had frequently met at Philadelphia, in what they finally called the Independence Hall, to prepare management of the coming independence. Probably, Europeans learnt from the British experience with America about independence, then they anticipated giving independence to their African colonies before the latter could become truly radical about their wanted independence, and get any true experience in the management of their own affairs. Truly, Africans were not prepared for their independence, and this can be seen from the fact that quickly soldiers took the power in most countries, and putsches became frequent on the continent. Contrarily to the American revolution with marked changes externally; the African revolution marked changes neither externally, nor internally; relations with the mother country have remained tough, exploitation, imposition and dependency have continued, and socially and economically the African people has known decreasing conditions. It might then be right to assert that there was no revolution at all in the African independence. Nevertheless, there remains a little parallel between theAmerican independence and the African independence: American revolution was directed against Europe the same way the African "revolution" was directed against Europe, and the paradox would not exist at all if only Americans had been really different from the Europeans, which was difficult to affirm since Americans are after all a species of Europeans, "the colony of all Europe" [2], as Thomas Paine put it in 1776, or the "daughter of Europe” [3], as General Charles de Gaulle remarked it in 1965.

\section{The Aftermath of the American and African Independences}

\subsection{The First Attempt of Union in America and in Africa}

The American struggle with England led to a change in American colonial attitudes. For instance, local colonial assemblies previously rejected a plan of union proposed by Albany (the Albany Plan of Union) in 1754, when Britain was still at war with France for the control of Canada, and when divergences with the mother country had not appeared yet. Then, the colonies refused the idea of surrendering even the smallest part of their individual autonomy to the profit of any other institution, even one that they would set up themselves. But in the course of the revolution for independence and in a projection of its aftermath, getting united appeared as an indispensable step towards an effective separation from Britain, and true sovereignty.

John Dickenson was the one who proposed in 1776, a document with articles that would get all the thirteen new states united. The document was called Articles of Confederation and Perpetual Union. Americans knew what a confederation means: the states got into a union, but remained individually sovereign. States were really not influenced by the union, and as such there was really no union. There was a supposed national government meant to regulate commerce and levy taxes, which were the principal revenues to the union survival. The union also had no control on the states' international relations, and then, individual states fixed their own norms and negotiations with foreign countries, including Britain. States organized their own armies, and had their own money enacting systems, all depreciating in value.

In Africa, there emerged no federal idea before independence, and when the African colonies got their independence, for the majority in 1960, they joined into a union in 1963, at Addis Ababa in Ethiopia, in what they also named the African Independence Hall. They set up the Organization of the African Unity (OAU). It would then not be awkward to make a parallel between the American Confederacy of 1776 and the OAU of 1963. Like the Articles of Confederation, OAU has had no influence on individual African states; this institution has never been capable to impose any decision on African states. It was just an opportunity for African leaders to meet and have a review over their personal influence, to have exchanges with their peers and get more experience in dominating their peoples. Even when decisions were taken at such conferences as the meeting of the OAU, states 
or Africans heads of states once at home, did not seem bond by them. Confident of this, the African leaders have acted freely and willingly against humans' rights while violating their own constitution. On the continent at large, the peoples, having had very different customs and traditions, and having been imposed very differing colonial rules, have never imagined of belonging to a union. As such, the OAU appeared as a conference of Africans heads of states rather than a tool for people's integration as it was pretended in the OAU charter.

In America, it was evident that the union was a false one with reference to the many internal crises, going from the indebted farmers' case, who were illegally put in jail, with reference to the Daniel Shays' militia and their actions against the courts to sit, and with reference to the inter-states frequent clashes. George Washington had even foreseen and forewarned when he said: "Our states are only united by a rope of sand” [1], then he continued that "there are combustible in every state, which a spark might set fire to" [1].

Yet, when dispute over navigation on the Potomac River broke out between Maryland and Virginia, Americans could not wait to see things grow worse and to favour the collapse of the union. In the case of African there has been more than what happened to the American confederation without the OAU to move: apartheid remained in South Africa, and the OAU could do nothing; political leaders like Patrice Lumumba from Democratic Congo and Thomas Sankara from Burkina Faso were assassinated without OAU to be concerned; putsches occurred here and there on the continent, with the instigators immediately becoming members of the organization. The 1994 Rwanda genocide occurred before the eyes of the organization. All these in a normal such environment would have been sufficient for Africa to see that their organization, as did American very early, was a loose one, and that there was an emergency for change, for progress. The emergency was even more evident for Africans to change their OAU than it appeared for Americans to change their confederation. For Americans however, it took just ten years to realize that need (1776 to 1787), and in practice it can be said it was less than that, since true independence came with the signing of the peace treaty in 1783. But Africans waited forty years (1963-2001) before they could realize the need for change.

\subsection{The United States of America and the African Union}

When representatives of five American states met in 1786 in Annapolis, Maryland, it was just to help Maryland and Virginia find a peaceful solution for their navigation on the Potomac river; it couldn't be anticipated that this would be the birth of a true union among the American states; and even when Alexander Hamilton convinced his colleagues to include all the states to the matter so as to prevent such clashes among other states, he could not for sure anticipate on the USA. Today, everyone agrees that America represents one of the most successful examples of union, and without this federal model, it is not evident that America would have emerged a super power economically, military and politically. Moreover, without even ever asserting at birth that they were a democracy, the USA has been giving democratic lessons today to many countries worldwide.

In 2001, African states finally felt the need to move, changing the OAU into the African Union (AU). But truly, what has been the difference between OAU and AU, and what changes have occurred on the continent since then? If there has been any single difference with OAU, the new African Union could, for instance, have prevented the contentions that took place (with some still going on) in countries such as Sudan, Burundi, Democratic Congo and Cote d'Ivoire, to name a few; or at least, it could have found quick and accurate solutions when the crisis broke out. Today, under the African Union, the African continent has had more challenges than ever with reference to the spread of constitutional putsches by more or less democratically elected presidents, who now wants to be presidents for life. There is the Touareg case in the North of Mali, the Boko-Haram, acting in the North of Nigeria, in Tchad and Cameroon, killing and kidnapping people with almost no resistance; there recently was the Ebola disease that killed so many people on the continent and in the central African region in particular. There also is the conflict about country borders, as has been the case with Benin and its neighbors of Niger, Burkina and even Togo and Nigeria. In such cases, the African countries are always obliged to refer to the former colonizers for solutions, which sounds a paradox. If, astonishingly, a single country like Nigeria can, from a personal initiative restore a destitute President in Gambia by a puschists, the whole African Union, despite all efforts, could not do likewise in Central Africa when Bozize drove Patasse from power. If France did not unilaterally act in Cote d'Ivoire the civil war in the country with Gbagbo and Ouattara as main protagonists would probably still be on the way; if the western countries did not intervene in the North of Mali, nobody can guess what would have already become of the whole country today; if the same western countries did not act against Ebola in Central Africa and the Lassa in Benin, the whole African continent would probably be in pro- 
gressive but hast depletion. Worse, the main actor of the birth of the African Union, to name MouhamarKadhafi, was attacked and assassinated before the eyes of his peers, all of them members of the African Union, by the international community, and France as the champion. In America, the federal government created by the constitution has had the mission to protect the states against invasion from outside and from strife and violence at home. It is true, the American states governments have generally been strong enough to maintain order within their own borders. But behind them stands the awesome power of the federal government, which is constitutionally empowered to make the necessary steps to preserve peace. Such strong federal organization is what Africa needs to stop internal disorder while hindering western manipulation, domination and exploitation, and this is still possible. One can still remember Pope Jean Paul II's call for Africans: “.... I'm sure that you can show the whole world that you are able to solve your own problems, though with a little assistance you'll need from Western powers at start...." [4] (My own translation from French).

It can rightly be alleged that African countries after independence had sensed the need for union, following the American experience. The course of African history would undoubtedly have differed in very little way from that of America, however, if only the African early leaders of the post-independence period had had a little sense of positive imitation. Now, why did they choose to go first through a weak union, like the Americans' confederation, knowing that the United States of America, the perfect federation of Americans 'states had existed almost a century before the African independence? Probably, it was the thirst of power from the early leaders who wanted to taste what it looked like to be a president, aided in this by the mother countries who would then still be on control. Now, all those wasted years won't be in favor of Africa in the search for prosperity, since that gap to fill has been daily increasing. Today, for Africa to catch time up and to get united, it will be necessary to go through intermediary steps first, such as regional federation of states.

\section{Conclusion}

If a solution could be attained based solely on the depths at which writers have tackled the African dilemma, then many of the present issues would be well on their way to being resolved. However, most of the literature continues to call for new systems of conducting the socio-economic and political life of the continent, without proposing how they could be conducted. And here lies the real difference with the present research work. This article, which is an analytic and comparative study, has explored the importance for African states to become united by using the American federal experience as a reference.

\section{References}

[1] Mellon, A (1998) An Outline of American History. US Information Agency, Washington DC.

[2] Thomas, P. (1983) Common Sense. Ed. Aubier Montaigne, Paris.

[3] Dumont, R. (1979) Black Africa Has Had a Bad Start. Edition Seuil, Paris.

[4] Pope John Paul II (1979) Speech Delivered in Cote d'Ivoire. Broadcast by RFI on April 4 2005. 